\title{
Modifying harvesting time as a tool to reduce nutrient export by timber extraction: a case study in planted teak (Tectona grandis L.f.) forests in Costa Rica
}

\author{
Jesús Fernández-Moya ${ }^{(1-2)}$, \\ Nur Algeet-Abarquero ${ }^{(2-3)}$, \\ Gilberto Cabalceta ${ }^{(2)}$, \\ Alfredo Alvarado ${ }^{(2)}$, \\ Alfonso San Miguel-Ayanz ${ }^{(1)}$, \\ Miguel Marchamalo-Sacristán (3)
}

\section{Introduction}

Forest plantations have increased globally during recent decades and now account for $290 \times 10^{6}$ ha, which is $7 \%$ of the global forest area, in response to the growing demand for timber, pulp, energy and other goods (Evans 2009, FRA 2015). At the same time, forest managers are becoming increasingly concerned about the relationship between forest nutrition, soil management and sustainable timber production, with the challenge of maintaining high pro-

\begin{abstract}
Despite its low nutrient concentration, the high amount of biomass accumulated in the tree stem makes it an important nutrient sink. Hence, nutrient loss through timber removal at harvesting is a major cause of nutrient impoverishment at some forest sites. The present study was designed to test the following hypotheses: (a) nutrient allocation in the different tree tissues would be affected by (re)translocation processes related with leaf senescence; hence, (b) timber may have a higher nutrient concentration during the defoliated period (in deciduous species); and consequently, (c) modifying harvesting time could influence nutrient export. To test these hypotheses, the present study analyzes the intra-annual dynamics of foliar and trunk nutrient concentration in a planted teak (Tectona grandis L.f.) forest in Costa Rica. Samples from nine trees were taken at nine sampling times between June 2012 and August 2013. The results confirm the above-mentioned hypotheses and reveal that modifying harvesting time have different consequences: (1) when harvesting occurs between August and October, it reduces the N-P-K exported through timber harvesting by $24-29-43 \%$; $(2)$ when harvesting occurs in December, the reduction is $28-29-14 \%$. Harvesting between August and October (rainy season) may involve logistical difficulties. Harvesting slightly earlier than usual (i.e., December, just after the rainy season but before leaf senescence) would therefore be an efficient approach to reducing nutrient export through timber extraction.
\end{abstract}

Keywords: Forest Nutrition, Soil Fertility, Soil Depletion, Sustainability, Forest Plantations, Nutrient Resorption

ductivity rates over several rotations, especially in short-rotation plantations (Nambiar 1995, Fox 2000). Repeated nutrient export through timber harvesting over several rotations could cause soil nutrient depletion (Miller 1984, Fölster \& Khanna 1997, Worrel \& Hampson 1997, Merino et al. 2005) and this may underlie the observed decrease in forest productivity over time (Rennie 1955, Evans 2009). This need to replace the nutrients lost (e.g., by fertilization) has traditionally been ignored by for- $\square$ (1) Dpto. Silvopascicultura, E.T.S.I. Montes, Universidad Politécnica de Madrid (UPM), Ciudad Universitaria s/n, 28040 Madrid (Spain); (2) Centro de Investigaciones Agronómicas, Universidad de Costa Rica (CIA-UCR), San Pedro (Costa Rica); (3) Dpto. Ingeniería y Morfología del Terreno, Universidad Politécnica de Madrid (UPM), Ciudad Universitaria s/n, 28040 Madrid (Spain)

@ Jesús Fernández-Moya (jesusfmoya@gmail.com)

Received: Jun 26, 2015 - Accepted: Feb 08, 2016

Citation: Fernández-Moya J, Algeet-Abarquero N, Cabalceta G, Alvarado A, San Miguel-Ayanz A, Marchamalo-Sacristán M (2016). Modifying harvesting time as a tool to reduce nutrient export by timber extraction: a case study in planted teak (Tectona grandis L.f.) forests in Costa Rica. iForest 9: 729-735. - doi: 10.3832/ifor1756-009 [online 2016-06-03]

Communicated by: Ana Rey est managers (Fölster \& Khanna 1997), although FSC (2004) and other authors (Rennie 1955, Worrel \& Hampson 1997, Merino et al. 2005) recommend the application of fertilizer to sustain short-cycle plantation productivity. Although nutrient inputs (mainly wet and dry depositions and mineral weathering) may partially compensate for these nutrient extractions, this is usually not sufficient when the extraction is high and/or the rotations are short (Worrel \& Hampson 1997).

Teak (Tectona grandis L.f.) is an important tropical hardwood species (Pandey \& Brown 2000, De Camino et al. 2002, De Camino \& Morales 2013), with a total planted area of $4.3 \times 10^{6}$ ha, of which 132,780 ha are in Central America (Kollert \& Cherubini 2012). A number of studies have addressed the question of soil fertility and nutrition in planted teak forests (for an overview, see Kumar 2011 and Alvarado 2012). For example, nutrient accumulation in aerial biomass of teak has been analyzed by several authors (Nwoboshi 1984, Kumar et al. 2009, Fernández-Moya et al. 2014, Jha 2014). Excessive nutrient export has been reported for teak plantations (FernándezMoya et al. 2011, 2014) and this could be related to the decline in productivity observed by some managers in the second 
Tab. 1 - Topsoil (0-40 cm) characteristics of 12 sampled plots in a teak (Tectona grandis L.f.) plantation in Santa Cruz, Guanacaste, Costa Rica. (ECEC): Effective cation exchange Capacity [ECEC = Acidity + Ca + Mg + K]; (AS): acidity saturation [AS = Acidity/ ECEC]; (*): critical values as reference levels to evaluate soil fertility in Costa Rica, as reported by Bertsch (1998) for general crops and by Alvarado \& Fallas (2004) for AS in teak plantations.

\begin{tabular}{|c|c|c|}
\hline Parameter & $\begin{array}{c}\text { Mean and } 95 \% \\
\text { confidence interval }\end{array}$ & $\begin{array}{l}\text { Critical } \\
\text { values* }\end{array}$ \\
\hline $\mathrm{pH}$ & $5.8(5.5,6.1)$ & 5.5 \\
\hline C org [\%] & $2.18(1.93,2.43)$ & - \\
\hline Sand [\%] & $41(33,49)$ & - \\
\hline Silt [\%] & $19(14,24)$ & - \\
\hline Clay [\%] & $39(36,42)$ & - \\
\hline Acidity $\left[\mathrm{cmol}(+) \mathrm{L}^{-1}\right]$ & $0.18(0.17,0.19)$ & 0.5 \\
\hline $\mathrm{Ca}\left[\mathrm{cmol}(+) \mathrm{L}^{-1}\right]$ & $18.3(17.08,19.52)$ & 4 \\
\hline $\mathrm{Mg}\left[\mathrm{cmol}(+) \mathrm{L}^{-1}\right]$ & $6.56(5.77,7.35)$ & 1 \\
\hline $\mathrm{K}\left[\mathrm{cmol}(+) \mathrm{L}^{-1}\right]$ & $0.37(0.28,0.46)$ & 0.2 \\
\hline $\operatorname{ECEC}\left[\mathrm{cmol}(+) \mathrm{L}^{-1}\right]$ & $25.41(23.5,27.32)$ & 5 \\
\hline AS [\%] & $0.7(0.6,0.8)$ & 3 \\
\hline $\mathrm{P}\left[\mathrm{mg} \mathrm{L}^{-1}\right]$ & $2(1,3)$ & 10 \\
\hline $\mathrm{Zn}\left[\mathrm{mg} \mathrm{L}^{-1}\right]$ & $1(1,1)$ & 3 \\
\hline $\mathrm{Cu}\left[\mathrm{mg} \mathrm{L}^{-1}\right]$ & $10(8,12)$ & 1 \\
\hline $\mathrm{Fe}\left[\mathrm{mg} \mathrm{L}^{-1}\right]$ & $49(36,62)$ & 10 \\
\hline $\mathrm{Mn}\left[\mathrm{mg} \mathrm{L}^{-1}\right]$ & $17(13,21)$ & 5 \\
\hline
\end{tabular}

and/or third rotations (Kollert \& Cherubini 2012). Timber extraction in the final felling at the end of the 20-year rotation period constitutes a major nutrient loss from the system, as the harvesting (wood and bark) of 150 teak trees ha ${ }^{-1}$ at an age of 19 years would export $220 \mathrm{~kg} \mathrm{~N} \mathrm{ha}^{-1}, 281 \mathrm{~kg} \mathrm{Ca} \mathrm{ha}^{-1}$, $88 \mathrm{~kg} \mathrm{~K} \mathrm{ha}{ }^{-1}, 63 \mathrm{~kg} \mathrm{Mg} \mathrm{ha}{ }^{-1}, 23 \mathrm{~kg} \mathrm{P} \mathrm{ha}{ }^{-1}, 39$ $\mathrm{kg} \mathrm{S} \mathrm{ha-1}, 6 \mathrm{~kg} \mathrm{Fe} \mathrm{ha}^{-1}, 129 \mathrm{~g} \mathrm{Mn} \mathrm{ha}^{-1}, 107 \mathrm{~g} \mathrm{Cu}$ $\mathrm{ha}^{-1}, 212 \mathrm{~g} \mathrm{Zn} \mathrm{ha}^{-1}$ and $401 \mathrm{~g} \mathrm{~B} \mathrm{ha}^{-1}$. Although this is a large loss in itself, the total nutrient extraction over one rotation is even larger as the timber extracted by thinnings, with a higher proportion of bark, also needs to be taken into account. Final felling nutrient extraction in teak plantations could be of special relevance in the case of $P$ and $K$, because of their low soil availability (Fernández-Moya et al. 2014). Due to the importance of teak plantations in Central American countries (Kollert \& Cherubini 2012), this species was chosen in order to analyze possible solutions to nutrient export and soil depletion.

In order to address the lack of sustainability and the possible decrease in long term production caused by nutrient depletion, authors of previous studies (Rennie 1955, Fölster \& Khanna 1997, Ma et al. 2007) have generally proposed the debarking of tree stems at the plantation site with the aim of minimizing nutrient export. However, this is considered an expensive, noncost effective and time-consuming practice by many forest managers and is currently not an option for forest companies in Central America.

Since teak is a deciduous species, nutrient allocation in the different tissues of the tree is affected by the (re)translocation processes related to leaf senescence (for a review, see Aerts 1996). Hence, hypothetically, timber will have a higher nutrient concentration during the dry season (defoliated teak period), when timber extraction is usually performed, than in the growing season when nutrients will be allocated to foliage (Fernández-Moya et al. 2014). Con-

Tab. 2 - Diameters at breast height (DBH, $\mathrm{cm}$ ) of trees sampled to monitor within-year foliar and trunk nutrient concentration in teak (Tectona grandis L.f.) plantations in Santa Cruz, Guanacaste, Costa Rica.

\begin{tabular}{lcccc}
\hline Sampling date & $\begin{array}{c}\text { Sample A } \\
\text { (trees 1, 2, 3) }\end{array}$ & $\begin{array}{c}\text { Sample B } \\
\text { (trees 4, 5, 6) }\end{array}$ & $\begin{array}{c}\text { Sample C } \\
\text { (trees 7, 8, 9) }\end{array}$ & $\begin{array}{c}\text { Total average } \\
\text { (trees 1 to 9) }\end{array}$ \\
\hline 26-Jun-12 & $35.1 \pm 5.9$ & $29.4 \pm 2.0$ & $28.1 \pm 5.8$ & $30.9 \pm 3.2$ \\
26-Aug-12 & $32.2 \pm 6.5$ & $31.8 \pm 3.5$ & $33.2 \pm 1.1$ & $32.4 \pm 2.2$ \\
7-Oct-12 & $32.5 \pm 4.1$ & $32.7 \pm 4.0$ & $32.0 \pm 3.6$ & $32.4 \pm 1.9$ \\
3-Dec-12 & $31.4 \pm 3.0$ & $33.1 \pm 1.9$ & $31.4 \pm 2.0$ & $32.0 \pm 1.3$ \\
27-Jan-13 & $33.0 \pm 4.3$ & $36.2 \pm 3.1$ & $33.1 \pm 5.8$ & $34.1 \pm 2.5$ \\
24-Feb-13 & $30.1 \pm 5.5$ & $31.9 \pm 1.6$ & $32.1 \pm 4.7$ & $31.4 \pm 2.2$ \\
21-Mar-13 & $28.6 \pm 5.1$ & $28.4 \pm 0.7$ & $30.9 \pm 5.1$ & $29.3 \pm 2.2$ \\
28-Jun-13 & $32.3 \pm 1.5$ & $33.2 \pm 3.9$ & $32.7 \pm 2.5$ & $32.7 \pm 1.4$ \\
12-Aug-13 & $32.5 \pm 4.9$ & $32.5 \pm 3.8$ & $33.1 \pm 2.6$ & $32.7 \pm 1.9$ \\
\hline
\end{tabular}

sequently, if this hypothesis is confirmed, modifying harvesting schedules would provide an efficient, cost effective approach to reducing nutrient export through timber harvesting. The present study analyzes foliar and trunk (wood and bark) intraannual nutrient concentration dynamics in planted teak forests in Guanacaste (Costa Rica), in order to examine the formulated hypotheses.

\section{Material and methods}

\section{Study area}

The present case study was conducted in a planted teak (Tectona grandis L.f.) forest located on the property of the Cabalceta family, in San Juan de Santa Cruz, Guanacaste, Costa Rica. According to Holdridge's life zones (Holdridge 1967), the region is bioclimatically classified as tropical moist forest, with a climate characterized by average annual precipitation of 2000$3000 \mathrm{~mm}$ and 4 to 6 dry months (December-April). The area has relatively fertile, reddish clayey soils described as Typic "Paralithic" Haplustalfs and Ultic Haplustalfs (Soil Survey Staff 2010) by Thiele (2008).

The exact location of the study was the "El Mango" stand $\left(10.211^{\circ} \mathrm{N}, 85.573^{\circ} \mathrm{W}\right)$ at an elevation of $115-120 \mathrm{~m}$ a.s.l. This is a mature stand planted on previously grazed land at the beginning of the study in 1989 (i.e., 23 years old in 2012). Low intensity thinning has led to an excessive density of 200-250 trees ha-1 in this stand. A total of 12 topsoil samples were collected $(0-40 \mathrm{~cm})$ and analyzed at CIA-UCR. Organic matter was determined using the combustion method as described by Horneck \& Miller (1998); pH was determined in water 10:25; acidity, $\mathrm{Ca}$ and $\mathrm{Mg}$ in $\mathrm{KCl}$ solution $1 \mathrm{M}$ 1:10; $\mathrm{P}$, $\mathrm{K}, \mathrm{Zn}, \mathrm{Fe}, \mathrm{Mn}$ and $\mathrm{Cu}$ in modified Olsen solution $\mathrm{pH} 8.5\left(\mathrm{NaHCO}_{3} 0.5 \mathrm{~N}\right.$, EDTA $0.01 \mathrm{M}$, Superfloc 127) 1:10. Soil texture was determined using the modified Bouyoucos method, as described by Forsythe (1975). Topsoil $(0-40 \mathrm{~cm})$ fertility results are summarized in Tab. 1, showing $\mathrm{P}, \mathrm{K}$ and $\mathrm{Zn}$ deficiencies.

\section{Sampling design and laboratory analyses}

Foliar and trunk nutrient concentration were monitored over nine sampling times from June 2012 to August 2013 (Tab. 2). Nine trees were randomly selected in order to obtain three composite samples of leaves and trunk at each sampling time; hence, they were placed in three groups of three trees each. Foliar samples were taken at a height of between 6 and $7 \mathrm{~m}$ using a sampling stick. Trunk samples were taken at $1.3 \mathrm{~m}$ height using an increment borer, hence a representative proportion of wood and bark were sampled. Diameter at breast height (1.3 $\mathrm{m}$ above the ground, hereafter DBH) of sampled trees was measured and is presented in Tab. 2. Fig. 1 presents images of the evolution of the stand at different sampling times over the 
Fig. 1 - Pictures of the sampled planted teak (Tectona grandis L.f.) forest in Guanacaste, Costa Rica, at June 2012 ( $a$ and $b)$ and January 2013 (c and d)
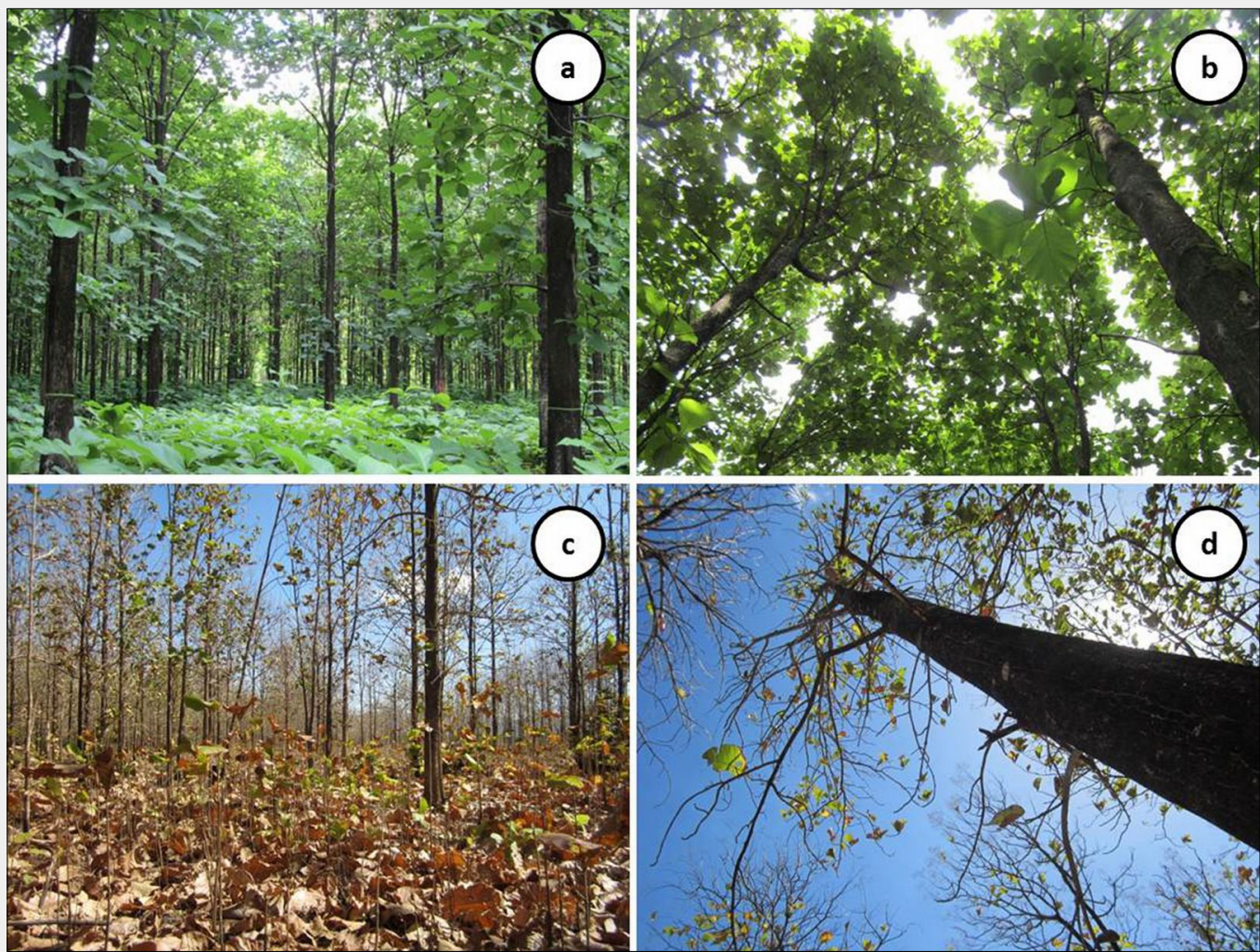

study period. Three samples of senesced leaves were collected from the soil surface (i.e., litterfall) in January, February and March (for a total of 9 samples) to estimate nutrient concentration after falling from the trees and to compare the results with the aforementioned foliar analysis.

Tissue samples were analyzed at the Centro de Investigaciones Agronómicas of the University of Costa Rica (CIA-UCR) to determine nutrient concentrations $(\mathrm{N}, \mathrm{P}, \mathrm{K}$, $\mathrm{Ca}, \mathrm{Mg}, \mathrm{S}, \mathrm{Fe}, \mathrm{Cu}, \mathrm{Zn}, \mathrm{Mn}$ and $\mathrm{B}$ ). Dry combustion was used to measure the $\mathrm{N}$ concentration, and wet digestion and atomic spectrometry were used to extract and determine the other nutrients (Bertsch 1998).

\section{Results and discussion}

\section{Foliar concentration dynamics}

Foliar nutrient concentration varies during the year with differing intensity de pending on the element, although the pattern presents very high variability (Fig. 2 and Fig. S1 in Supplementary material). This variation can mainly be attributed to the widely analyzed retranslocation processes (Van Den Driessche 1984, Aerts 1996, Fife et al. 2008). In addition, litterfall nutrient concentration (Fig. S2 in Supplementary material) generally shows lower values compared to those of green non-senescing leaves, supporting the aforementioned nutrient resorption or (re)translocation theory. This process is considered a nutrient conservation mechanism which allows the plants to maintain a reservoir of nutrients which are readily available for further plant growth, while on the other hand, non-resorbed nutrients circulate through the litterfall and part of them eventually become available for future plant uptake (Vitousek 1984, Aerts 1996). These processes are of special importance in tropical rainy climates, where the non-resorbed nutrients circulating through litterfall can result in high nutrient lixiviation losses and hence site impoverishment (Bruijnzeel 1991), even though the rapid decomposition rate of organic matter reduces the time needed for nutrients to become available to plants again (Vitousek 1984).

Aerts (1996) reported that around 54\% of foliar $\mathrm{N}$ and $50 \%$ of foliar $\mathrm{P}$ (the only two elements analyzed) retranslocate before senescence as a general pattern in deciduous species, even though he also found a high variability in the data. Singh (2004) reported nutrient resorption specifically associated with teak foliage senescence. In the present case study, foliar $\mathrm{N}$ concentration remained between 1.5 and $1.8 \%$ between June and December 2012 and decreased to 0.8 and $1 \%$ in January and February, when leaves are senescing (Fig. 2). In contrast, as $\mathrm{Ca}, \mathrm{Fe}$ and $\mathrm{Cu}$ are non-mobile nutrients they accumulated in the leaves and the lack of a retranslocation process was evident (Fig. 2 and Fig. S1 in Supplementary material). This pattern has been observed by other authors, at least with regard to the lack of $\mathrm{Ca}$ retranslocation (Saur et al. 2000, Fife et al. 2008).

Retranslocation can be also observed in the $\mathrm{P}, \mathrm{K}$ and $\mathrm{Zn}$ foliar concentration results (Fig. 2 and Fig. S1 in Supplementary material). However, compared with $\mathrm{N}$, the process followed a much less clear pattern for these nutrients, due to the large differ- ence found between their foliar concentration in the 2012 growing season compared with that of 2013 (Fig. 2 and Fig. S1 in Supplementary material). While $\mathrm{P}$ resorption coincides in time with the observed $\mathrm{N}$ resorption between December and January, $\mathrm{K}$ resorption is observed slightly later (between January and February) and Zn a little earlier (between October and December - Fig. 2 and Fig. S1 in Supplementary material). $\mathrm{K}$ is a mobile nutrient that plays key roles in photosynthesis and $\mathrm{CO}_{2}$ assimilation and exerts a regulatory effect on stomatal movement and transpiration rates. Hence, normal $\mathrm{K}$ concentration values are probably sustained until the last stages of senescence (January-February) in order to maintain transpiration. Foliar $\mathrm{K}$ losses might also be expected in the rainy period as this element can be washed out. However, this tendency is not observed in the collected data, though it may explain the higher variability of $\mathrm{K}$ foliar concentration in October compared to August and December (Fig. 2).

The establishment of foliar concentration references is considered a useful tool to evaluate the nutritional status of a stand and foliar analysis has been used for diagnostic purposes and for designing nutritional and fertilization plans (Richards \& Bevege 1972, Mead 1984, Drechsel \& Zech 1991). However, as foliar concentration varies over the year (Fig. 2 and Fig. S1 in Supplementary material), the foliar concentration reference should establish a clear temporal framework to be applied, and this should be carefully taken into account by the reference users, i.e., forest managers. Richards \& Bevege (1972) identified two 

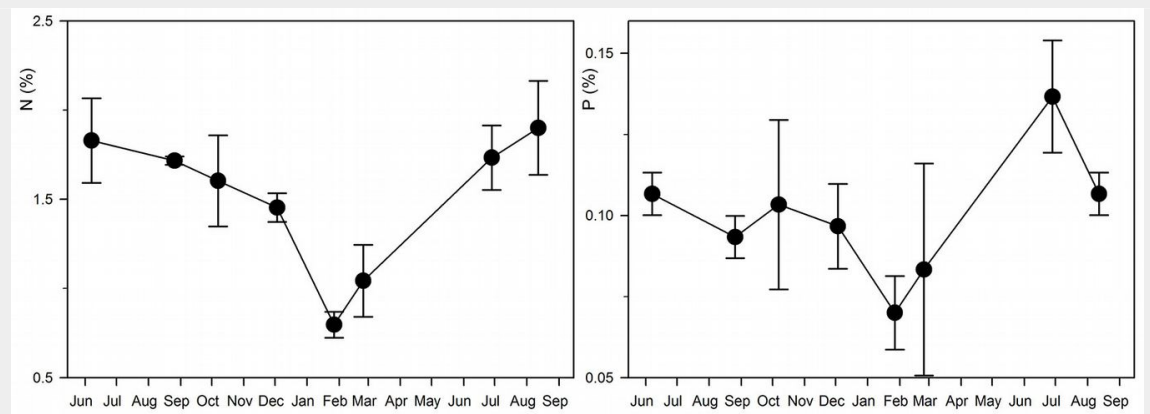

Fig. 2 - Macronutrient foliar concentration variations over time (from June 2012 to August 2013) in a planted teak (Tectona grandis L.f.) forest in Guanacaste, Costa Rica. Mean and $95 \%$ confidence interval are shown for each sampling time.
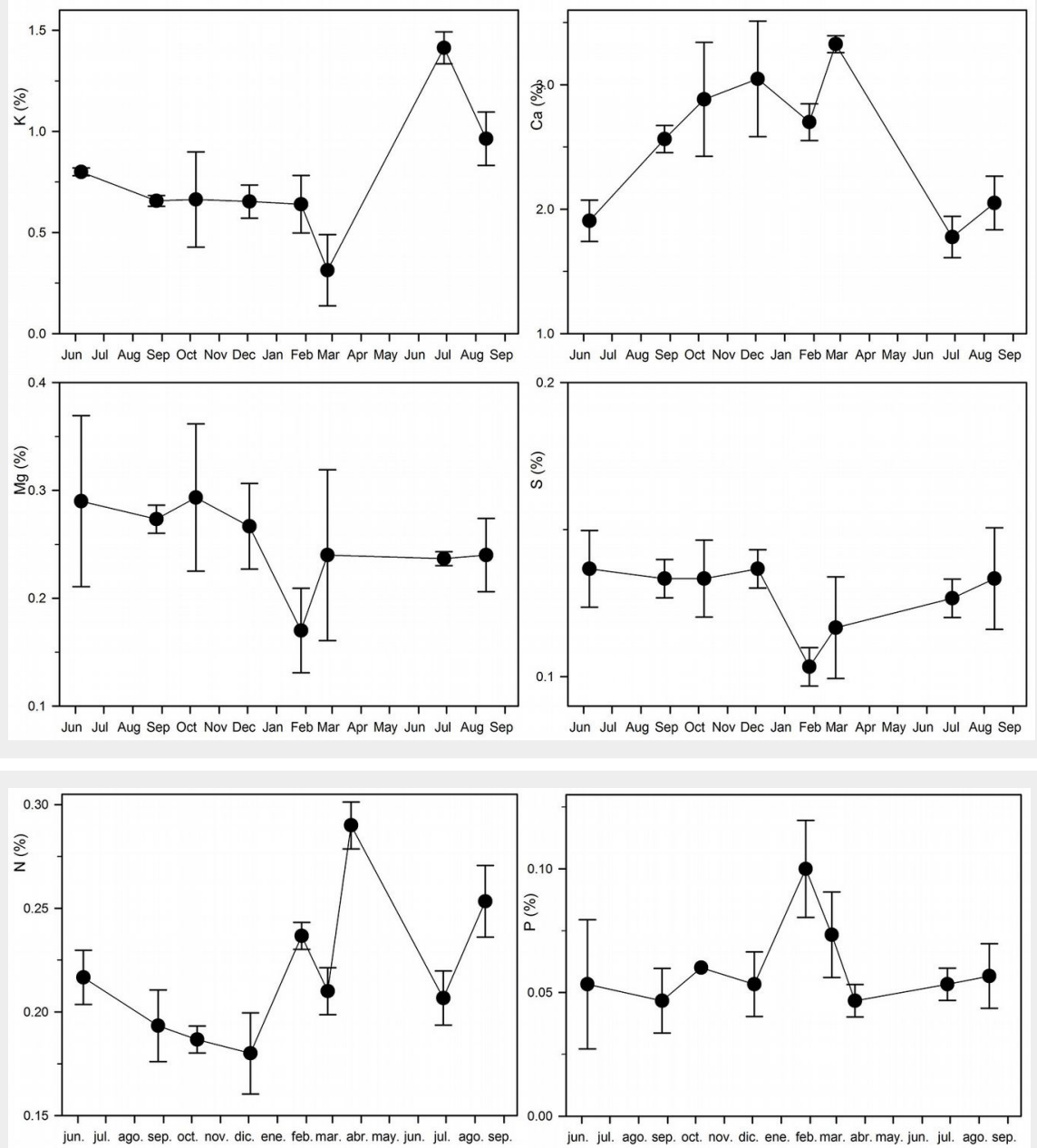

Fig. 3 - Macronutrient trunk (wood and bark) concentration variations over time (from June 2012 to August 2013) in a planted teak (Tectona grandis L.f.) forest in Guanacaste, Costa Rica. Mean and $95 \%$ confidence interval are shown for each sampling time.
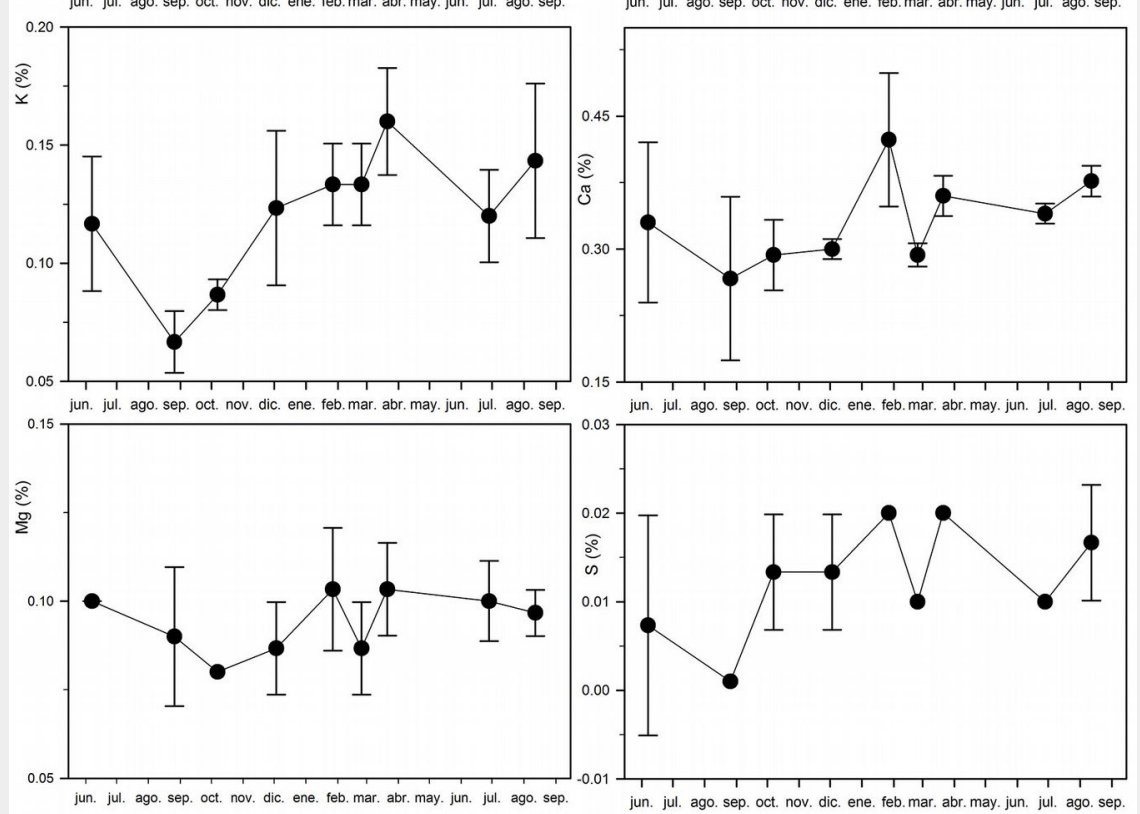
additional problems related to the practical use of foliar concentration references which are evident in the results of this study (Fig. 2 and Fig. S1 in Supplementary material): (1) large differences between trees; and (2) large differences between years, which can be even larger than between trees. Raupach (1967) and Richards \& Bevege (1972) recommend sampling at least six trees from each stand and analyzing them either singly or in composite samples of three trees, in order to obtain a representative estimation which takes into account this tree-to-tree variation. These recommendations were heeded in the present study; three composite samples (of three trees each) were analyzed each time. Further research needs to be conducted, extending the present experimental design over several years in order to take the year-to-year variation into account.

\section{Trunk concentration dynamics}

The observed increase in $\mathrm{N}$ concentration in the trunk corresponds with the previously mentioned decrease in $\mathrm{N}$ concentration in senescing leaves (Fig. 2 and Fig. 3). $\mathrm{N}$ concentration in the trunk remains between 0.18 and $0.19 \%$ between August and December 2012 and increases to $0.24,0.21$ and $0.29 \%$ in January, February and March, respectively (Fig. 3). A similar but somewhat less intense pattern can be observed for $\mathrm{P}$ concentration in the trunk, which remains between 0.05 and $0.06 \%$ between August and December 2012 and increases to 0.1 and $0.07 \%$ in January and February, respectively (Fig. 3). A slightly different pattern can be observed for $\mathrm{K}$ concentration in the trunk, which is estimated to be 0.07 and $0.09 \%$ in August and October 2012 and increases to be between 0.12 and 0.16 during the rest of the year (Fig. 3). On the other hand, no evident pattern was observed for the concentration of the other nutrients in the trunk (Fig. 3 and Fig. $\mathrm{S}_{3}$ in Supplementary material).

The increase in $\mathrm{N}$ and $\mathrm{P}$ concentration in the trunk between December and January corresponds directly with the decrease in foliar concentration shown at the same time (Fig. 2 and Fig. 3). This is in accordance with the previously discussed resorption process, as nutrients are retranslocated to the wood, bark, branches and roots when the leaves begin the senescence process (Van Den Driessche 1984, Aerts 1996, Fife et al. 2008). This pattern is different to that of the foliar $\mathrm{K}$ concentration, which exhibits the resorption process slightly later (between January and February, as previously mentioned) and the greater increase in trunk concentration slightly earlier, between October and December (Fig. 2 and Fig. 3). Hence, the main variation in trunk $\mathrm{K}$ concentration may not be caused by the leaf senescence resorption processes, but rather because of a different physiological mechanism. The low trunk $\mathrm{K}$ concentration period could be seen as a decrease between June and August instead of the above-mentioned increase between October and December (Fig. 3). In fact, a decrease in foliar $\mathrm{K}$ concentration is also observed between June and August, both in 2012 and 2013 (Fig. 2). Flowering (between June and September) could be the main cause of these decreases in both foliar and trunk concentrations, due to the mobilization of $\mathrm{K}$ from those tissues to flowers. Flowers have been identified as the nutrient sink tissue with the highest nutrient concentration in teak plantations (Kumar et al. 2009).

Trunk nutrient concentration is very low compared to foliar concentration (Fig. 2 and Fig. 3, Fig. S1 and Fig. S3 in Supplementary material). Nevertheless, the high amount of biomass accumulated in the tree stem makes it an important nutrient sink. As a consequence, the loss of nutrients through wood removal at harvesting is considered a major cause of nutrient impoverishment in forest sites (Rennie 1955, Fölster \& Khanna 1997, Worrel \& Hampson 1997). Our results show that the trunk nutrient concentration varies over the course of the year (Fig. 3, Fig. S3 in Supplementary material), confirming the hypothesis stated in the introduction section (Fernández-Moya et al. 2014). Thus, harvesting time influences the amount of nutrients extracted through wood removal. However, teak is usually harvested in the dry period to minimize the impact on the site as well as for operational and logistic reasons (De Camino \& Morales 2013). The way in which this affects management decisions is further discussed below. Based on the results of this study, changing the time of harvesting will have the following effects:

- Timber harvested in the dry period (January to March) has an average N-P-K concentration of $0.25,0.07$ and $0.14 \%$, respectively, while the nutrient concentration is $0.19,0.05$ and $0.08 \%$, respectively, if harvested between August and October. Thus a reduction of 24,29 and $43 \%$ of the $\mathrm{N}-\mathrm{P}-\mathrm{K}$ exported through timber harvesting can be achieved under this scenario.

- Timber harvested in December has an average N-P-K concentration of $0.18,0.05$ and $0.12 \%$, respectively, which will reduce the N-P-K exported through timber harvesting by 28,29 and $14 \%$ compared to the N-P-K exported when timber is harvested in the dry period (January to March).

Based on the present results, harvesting between August and October would mean a major reduction in N-P-K export, due to the lower concentration of these nutrients in the wood and bark during that period of the year. However, this period may present certain logistic problems for harvesting operations, as it falls within the normal rainy period. A possible solution may be to perform some of the harvesting operations at this time (e.g., cutting), leaving the trees in the field until the dry period, when their removal is easier. However, this option should be examined carefully, as it may increase the risk of pests and diseases or significantly increase the operational costs. Another alternative could be to harvest in December (slightly earlier than normal), at the beginning of the dry period but before leaf senescence occurs. This option will reduce operational difficulties while also minimizing nutrient export, as the nutrient concentration in the wood and bark is lower than later on in the dry period.

Nutrient export through timber harvesting has been reported to be of specific importance for $\mathrm{N}, \mathrm{P}$ and $\mathrm{K}$ in the various teak plantations studied in Central America (Fernández-Moya et al. 2014). N and Ca are the nutrients with highest nutrient export values (220 kg N ha-1, $281 \mathrm{~kg} \mathrm{Ca} \mathrm{ha}^{-1}$ ), although in the case of $\mathrm{Ca}$ there is no sustainability issue due to its large soil reservoir (Fernández-Moya et al. 2014). $\mathrm{N}$ sustainability could not be estimated in previous studies due to the lack of information on soil $\mathrm{N}$, though it is considered to be the limiting nutrient in many forest ecosystems (Hedin et al. 2009). Although the estimated amount of $\mathrm{P}$ and $\mathrm{K}$ exported through timber harvesting ( $88 \mathrm{~kg} \mathrm{~K} \mathrm{ha}^{-1}$ and $23 \mathrm{~kg} \mathrm{P}$ $\mathrm{ha}^{-1}$ ) is much lower than $\mathrm{N}$, the loss of these nutrients implies a sustainability problem for the system, as the soils where teak plantations are generally established in Central America have very low $\mathrm{P}$ and $\mathrm{K}$ content (Fernández-Moya et al. 2014). Hence, a reduction in N-P-K export through timber extraction would be of great importance for long-term site productivity.

This study provides promising results which could lead to an improvement in nutrient management and planted forest sustainability. However, a more detailed study over several years with a larger number of samples and locations is necessary to confirm the observed trends. Furthermore, future research should be aimed at analyzing the differences in trunk nutrient concentration along the stem at different heights (Helmisaari \& Siltala 1989, SaintAndre et al. 2002). In this study, trunk sampling was performed at a height of $1.3 \mathrm{~m}$ (diameter at breast height). Sampling the trunk at higher points might reveal an even more intense influence of the leaf senescence retranslocation processes, as the sampling point would be closer to crown. In addition, a wider approach should also consider the nutrient export associated with seed collection, although the impact of this process on seasonal variation is expected to be low. Similarly, root dynamics has to be also considered, as small root senescence and regrowth likely follow a similar pattern to that observed in the foliage. Finally, the variability of teak phenology depending on climate at a specific site should also be taken into account. For example, teak shows a marked deciduous behavior in Northern Costa Rica, as discussed in this paper, while it behaves as an evergreen in the more humid Southern 
Costa Rica, where there is no distinct summer season.

Several authors have studied the temporal and spatial (radial and height variation) nutrient dynamics within stem wood and have highlighted a general tendency for nutrient translocation from senescing sapwood and hardwood to active sapwood (Helmisaari \& Siltala 1989, Andrews et al. 1999, Laclau et al. 2001, Meerts 2002, SaintAndre et al. 2002). However, to our knowledge, no other study has evaluated the possibility of using this natural phenomenon to minimize nutrient removal through wood harvesting.

\section{Conclusions}

The results of this study reveal the influence of nutrient resorption or (re)translocation processes associated with leaf senescence in the intra-annual dynamics of foliar and trunk nutrient concentration in planted teak forests. This confirms the hypothesis that trunk nutrient content is lower during wet periods, when the teak trees are in foliage. Therefore, shifting harvesting time can be an efficient approach to reduce nutrient export through timber extraction. Indeed, harvesting between August and October will reduce the N-P-K exported by 24,29 and $43 \%$, respectively, as compared with the conventional harvesting time carried out during the dry period (January-March). However, the period August-October corresponds to the rainy season in northern Costa Rica, and this rises several logistical and operational difficulties. Alternatively, harvesting in December - at the beginning of the dry period but before leaf senescence - will minimize the operational and logistical difficulties, whilst reducing the N-P-K exported by 28,29 and $14 \%$, respectively.

\section{Acknowledgments}

We acknowledge the kind collaboration of the Cabalceta family for allowing the use of their private forests to conduct this study, and in particular Edwin Cabalceta Yurien Gutiérrez (Pilo), Sabas Elijio Ortiz (Saba) and Randall Iván González for their help during the fieldwork. The authors also thank Adam Collins and the personnel of the Natural Resources Laboratory at $\mathrm{CIA}$ (UCR) for their help and comments in the production of this paper. This study was financed by PCI-AECID as part of the MACOSACEN Project.

\section{References}

Aerts R (1996). Nutrient resorption from senescing leaves of perennials: are there general patterns? Journal of Ecology 84: 597-608. - doi: $10.2307 / 2261481$

Alvarado A (2012). Nutrición y fertilización de Tectona grandis Linn. f. [Tectona grandis Linn. f. nutrition and fertilization] In: "Nutrición y fertilización forestal en regiones tropicales" (Alvarado A, Raigosa J eds). Asociación Costarricense de las Ciencias del Suelo, San José, Costa Rica, pp. 313-340. [in Spanish]
Alvarado A, Fallas JL (2004). La saturación de acidez y el encalado sobre el crecimiento de la teca (Tectona grandis L. f.) en suelos ácidos de Costa Rica [Effects of acidity saturation and liming over teak (Tectona grandis L.f.) growth in acid soils from Costa Rica]. Agronomía Costarricense 28 (1): 81-87. [in Spanish]

Andrews J, Siccama TG, Vogt KA (1999). The effect of soil nutrient availability on retranslocation of $\mathrm{Ca}, \mathrm{Mg}$ and $\mathrm{K}$ from senescing sapwood in Atlantic white cedar. Plant and Soil 208: 117-123. - doi: 10.1023/A:1004512317397

Bertsch F (1998). La fertilidad de los suelos y su manejo [Soil fertility and its management]. Asociación Costarricense de la Ciencia del Suelo, San José, Costa Rica. [in Spanish]

Bruijnzeel LA (1991). Nutrient input-output budgets of tropical forest ecosystems: a review. Journal of Tropical Ecology 7: 1-24. - doi: 10.1017/ So266467400005010

De Camino R, Alfaro MM, Sage LFM (2002). Teak (Tectona grandis) in Central America. FAO Plantations Working Papers FP/19, Rome, Italy, pp. 57.

De Camino R, Morales JP (2013). Las plantaciones de teca en América Latina: mitos y realidades [Teak plantations in Latinamerica: myths and reality]. Centro Agronómico Tropical de Investigación y Enseñanza (CATIE), Turrialba, Costa Rica, pp. 392. [in Spanish]

Drechsel P, Zech W (1991). Foliar nutrient levels of broad-leaved tropical trees: a tabular review. Plant and Soil 131 (1): 29-46. [online] URL: http://link.springer.com/article/10.1007/BF00010 417

Evans J (2009). Planted forests: uses, impacts and sustainability. CAB International, FAO, Rome, Italy, pp. 213. [online] URL: http://books. google.com/books?id=FUXXvmChRF4C

Fernández-Moya J, Alvarado A, San MiguelAyanz A, Marchamalo-Sacristán M (2011). Uso sostenible de nutrimentos en plantaciones de teca (Tectona grandis L. f.) en América Central: implicaciones para la certificación. In: Proceedings of the International Conference "Bosques plantados de teca - un recurso forestal emergente a nivel global". CATIE-TEAKNET-FAO, Turrialba (Costa Rica) 31 Oct - 2 Nov 2011, Poster session. [in Spanish]

Fernández-Moya J, Murillo R, Portuguez E, Fallas JL, Ríos V, Kottman F, Verjans JM, Mata R, Alvarado A (2014). Nutrient accumulation and export in teak (Tectona grandis L. f.) plantations of Central America. iForest 8 (1): 33-44. doi: 10.3832/ifor1089-007

Fife DN, Nambiar EKS, Saur E (2008). Retranslocation of foliar nutrients in evergreen tree species planted in a Mediterranean environment. Tree Physiology 28: 187-196. - doi: 10.1093 /treephys/28.2.187

Fölster H, Khanna PK (1997). Dynamics of nutrient supply in plantation soils. In: “Management of Soil, Nutrients and Water in Tropical Plantation Forests" (Nambiar EKS, Brown AG eds). Australian Centre for International Agricultural Research, Bruce, ACT, Australia, pp. 339-379. Forsythe W (1975). Física de suelos. Manual de laboratorio [Soil physics. Laboratory manual]. IICA, San. José, Costa Rica, pp. 212. [in Spanish] Fox TR (2000). Sustained productivity in intensively managed forest plantations. Forest Ecol- ogy and Management 138: 187-202.

doi: 10.1016/S0378-1127(00)00396-0

FRA (2015). Global forest resources assessment 2015. FAO, Rome, Italy, pp. 253. [online] URL: http://www.fao.org/3/a-i4808e.pdf

FSC (2004). Perspectivas sobre plantaciones: desafío para el manejo de plantaciones [Perspectives on plantations: challenges over plantation management]. Forest Stewardship Council, A. C. Bonn, Germany, pp. 18. [in Spanish]

Hedin LO, Brookshire ENJ, Menge DNL, Barron $A R$ (2009). The nitrogen paradox in tropical forest ecosystems. Annual Review of Ecology, Evolution, and Systematics 40: 613-635. - doi: 10.1146/annurev.ecolsys.37.091305.110246 Helmisaari HS, Siltala T (1989). Variation in nutrient concentrations of Pinus sylvestris stems. Scandinavian Journal of Forest Research 4 (14): 443-451. - doi: $10.1080 / 02827588909382580$ Holdridge LR (1967). Life zone ecology. Tropical Science Center, San José, Costa Rica, pp. 149. Horneck DA, Miller RO (1998). Determination of total nitrogen in plant tissue. In: "Handbook of reference methods for plant analysis" (Kalra YP ed). Soil and Plant Analysis Council Inc. and CRC Press, Boca Raton, FL, USA, pp. 75-83. [online] URL: http://books.google.com/books?id=wLgg XPmhY18C

Jha KK (2014). Temporal patterns of storage and flux of $N$ and $P$ in young teak plantations of tropical moist deciduous forest, India. Journal of Forestry Research 25 (1): 75-86. - doi: 10.1007/s11676-014-0433-6

Kollert W, Cherubini L (2012). Teak resources and market assessment 2010. FAO Planted Forests and Trees Working Paper FP/47/E, Rome, Italy, pp. 4. [online] URL: http://teaknet.org/system/ files/Volume5Issue2(1).pdf

Kumar BM (2011). Soil management in teak plantations. In: Proceedings of the International Training Programme "Innovations in the Management of Planted Teak Forests" (Jayaraman $\mathrm{K}$, Bhat KV eds). TEAKNET/Kerala Forest Research Institute, Peechi, India, pp. 24-30.

Kumar JIN, Kumar RN, Kumar BR, Sajish PR (2009). Quantification of nutrient content in the aboveground biomass of teak plantation in a tropical dry deciduous forest of Udaipur, India. Journal of Forests Science 55 (6): 251-256. [online] URL: http://www.agriculturejournals. cz/publicFiles/06923.pdf

Laclau JP, Bouillet JP, Ranger J, Joffres R, Gouma R, Saya A (2001). Dynamics of nutrient translocation in stemwood across an age series of a eucalyptus hybrid. Annals of Botany 88: 1079-1092. - doi: 10.1006/anbo.2001.1550

Ma X, Heal KV, Liu A, Jarvis PG (2007). Nutrient cycling and distribution in different-aged plantations of Chinese fir in southern China. Forest Ecology Management 243: 61-74. - doi: 10.1016/ j.foreco.2007.02.018

Mead DJ (1984). Diagnosis of nutrient deficiencies in plantations. In: "Nutrition of Plantation Forests" (Bowen GD, Nambiar EKS eds). Academic Press, London, UK, pp. 259-292.

Meerts P (2002). Mineral nutrient concentrations in sapwood and heartwood: a literature review. Annals of Forest Science 59: 713-722. doi: 10.1051/forest:2002059

Merino A, Balboa MA, Rodríguez-Soalleiro R, Alvarez González JG (2005). Nutrient exports 
under different harvesting regimes in fastgrowing forest plantations in southern Europe. Forest Ecology and Management 207 (3): 325339. - doi: 10.1016/j.foreco.2004.10.074

Miller HG (1984). Dynamics of nutrient cycling in plantation ecosystems. In: "Nutrition of Plantation Forests" (Bowen GD, Nambiar EKS eds). Academic Press, London, UK, pp. 53-79.

Nambiar EKS (1995). Sustained productivity of plantations: science and practice. Bosque 16 (1): 3-8. - doi: 10.4206/bosque.1995.v16n1-01 Nwoboshi LC (1984). Growth and nutrient requirements in a teak plantation age series in Nigeria. II. Nutrient accumulation and minimum annual requirements. Forest Science 30 (1): 3540. [online] URL: http://www.ingentaconnect. com/content/saf/fs/1984/00000030/00000001/ artoooo8

Pandey D, Brown C (2000). Teak: a global overview. Unasylva 51 (2): 1-15. - [online] URL: http:// citeseerx.ist.psu.edu/viewdoc/download? doi=10.1.1.483.8815\&rep=rep1\&type=pdf Raupach M (1967). Soil and fertilizer requirements for forests of Pinus radiata. Advances in Agronomy 19: 307-353. - doi: 10.1016/S0065-2113 (08)60738-5

Rennie PJ (1955). The uptake of nutrients by mature forest growth. Plant and Soil 8 (1): 4995. - doi: $10.1007 / B F 01343546$

Richards BN, Bevege DI (1972). Principles and practice of foliar analysis as a basis for crop-logging in pine plantations: 1 . Basic considerations. Plant and Soil 36: 109-119. - doi: 10.1007/BF013 73461
Saint-Andre L, Laclau JP, Deleporte P, Ranger J, Gouma R, Saya A, Joffre R (2002). A generic model to describe the dynamics of nutrient concentrations within stemwood across an age series of a Eucalyptus hybrid. Annals of Botany 90: 65-76. - doi: 10.1093/aob/mcf146

Saur E, Nambiar EKS, Fife DN (2000). Foliar nutrient retranslocation in Eucalyptus globulus. Tree Physiology 20: 1105-1112. - doi: 10.1093/treephys/ 20.16.1105

Singh A (2004). Effect of fertilization on N and P resorption efficiency of selected leguminous and non leguminous tropical trees planted on coal mine spoil. Journal of the Indian Institute of Science 84: 173-182.

Soil Survey Staff (2010). Keys to Soil Taxonomy ( $11^{\text {th }}$ edn). USDA and Natural Resources Conservation Service, Nebraska, USA, pp. 346. [online] URL: http://www.nrcs.usda.gov/wps/ PA NRCSConsumption/download?cid=nrcs142p 2_050915\&ext=pdf

Thiele H (2008). Variables edáficas que afectan el crecimiento de la teca (Tectona grandis L. f.) en la vertiente del Pacífico de Costa Rica [Soil variables effect over teak (Tectona grandis L.f.) growth in the Pacific coast of Costa Rica]. MSC Tesis, Universidad de Costa Rica, San José, Costa Rica, pp. 184. [in Spanish]

Van Den Driessche R (1984). Nutrient storage, retranslocation and relationship of stress to nutrition. In: "Nutrition of plantation forests" (Bowen GD, Nambiar EKS eds). Academic Press, London, UK, pp. 181-209.

Vitousek PM (1984). Litterfall, nutrient cycling, and nutrient limitation in tropical forests. Ecology 65: 285-298. - doi: 10.2307/1939481

Worrel R, Hampson A (1997). The influence of some forest operations on the sustainable management of forest soils - a review. Forestry 70 (1): 61-85. - doi: 10.1093/forestry/70.1.61

\section{Supplementary Material}

Fig. S1 - Micronutrient foliar concentration variations over time (from June 2012 to August 2013) in a planted teak (Tectona grandis L.f.) forest in Guanacaste, Costa Rica. Mean and 95\% confidence interval is shown for each sampling time.

Fig. S2 - Litter nutrient concentration variations over time (from January 2013 to March 2013) in a planted teak (Tectona grandis L.f.) forest in Guanacaste, Costa Rica. Mean and 95\% confidence interval is shown for each sampling time.

Fig. S3 - Micronutrient trunk (wood and bark) concentration variations over time (from June 2012 to August 2013) in a planted teak (Tectona grandis L.f.) forest in Guanacaste, Costa Rica. Mean and 95\% confidence interval is shown for each sampling time.

Link: Fernandez-Moya_1756@supplo01.pdf 